Revista de la red interuniversitaria de estudios sobre las literaturas rioplatenses contemporáneas en Francia

$11 \mid 2014$

De niños e infancias

\title{
Uno de Abejas y uno de Chesterton
}

\section{Alejandro Crotto}

URL: http://journals.openedition.org/lirico/1843

DOI: $10.4000 /$ lirico.1843

ISSN: 2262-8339

Editor

Réseau interuniversitaire d'étude des littératures contemporaines du Río de la Plata

Referencia electrónica

Alejandro Crotto, « Uno de Abejas y uno de Chesterton », Cuadernos LIRICO [En línea], 11 | 2014, Puesto en línea el 01 diciembre 2014, consultado el 19 abril 2019. URL : http://journals.openedition.org/ lirico/1843 ; DOI : 10.4000/lirico.1843

Este documento fue generado automáticamente el 19 abril 2019.

\section{(c) (i) (9)}

Cuadernos LIRICO está distribuido bajo una Licencia Creative Commons Atribución-NoComercialSinDerivar 4.0 Internacional. 


\title{
Uno de Abejas y uno de Chesterton
}

\author{
Alejandro Crotto
}

\section{NOTA DEL EDITOR}

Alejandro Crotto (Buenos Aires, 1978). Publicó los libros de poemas Abejas (Bajo la luna, 2009) y Chesterton (Bajo la luna, 2013). Ha publicado trabajos de crítica y poemas en las revistas literarias Diario de Poesía, Letras libres y Hablar de Poesía ; y ha participado en varias antologías. Administra el sitio web www.losporquesdelarosa.blogspot.com dedicado a la traducción de poesía.

\section{Las palomas}

1 Hay que ponerse rápido las medias porque el piso de piedra está frío ; en la cocina desayunamos leche, pan con manteca y miel, después salimos a cazar palomas con nuestro rifle de aire comprimido, mi hermano y yo con menos de once años $\mathrm{y}$ con botas de goma, camisa gruesa a cuadros y balines en el bolsillo -dos o tres, los próximos a usar, van en la boca.

Vamos dejando huellas en la helada que empieza a deshacerse, vamos alerta entre las ramas de los plátanos, los altos eucaliptos, el nogal, las casuarinas, los álamos del haras, la pileta, un tiro cada uno, caminando, señalando de a ratos las copas del otoño.

Después, detrás del lavadero, entre frutales, 
las desplumamos y las destripamos :

sosteniendo en la izquierda el peso tibio

vamos sacando plumas con la otra,

las más largas y duras en la cola y el ala,

las fáciles del pecho,

las cortitas y oscuras de la espalda, las más suaves

en el flanco, debajo de las alas en la axila ;

van quedando en los yuyos enredadas hacia el lado del viento,

pegadas en las manos, suspendidas del aire

cuando se arremolina de repente ;

después vamos vaciando el cuerpo, mucho más chico

ahora en relación a la cabeza : primero el buche,

a veces con semillas de girasol intactas que se pueden comer,

apenas agrias, y metiendo con fuerza los dedos hacia arriba

donde termina el esternón, girándolos

dentro del cuerpo todavía caliente, agarrando y tirando para abajo,

arrancamos los largos intestinos y la panza, sacamos los pulmones

como una esponja rosa pegada a las costillas,

los riñones, el hígado, el quieto corazón,

que los perros atrapan sin que toquen

el suelo ; en la canilla lavamos las palomas

y les cortamos la cabeza, las atamos

subidos a un banquito de la pata a un alambre hasta la noche.

Las manos queman por el frío del agua,

brillan los cuerpos en el aire, al sol ; la vida

es material, y la materia

es difícil, sagrada.

\section{La lambersiana}

Detrás de la pileta hay una lambersiana

del color del limón. Es mediodía

y reverbera el aire en el calor

de febrero y la quieta resolana. Los grandes

ya se fueron a misa,

van a rezarle a Dios, que no se ve y es santo ;

mientras tanto los primos nos metemos al agua,

nos secamos tirados entre risas al sol.

Después yo entré en la lambersiana. Era otro mundo

ahí dentro, como ver otro lado en las cosas,

lo que las sostenía. Afuera los penachos amarillos

en el aire caliente, y una estructura adentro

de ramas resinosas y la luz, la fresca luz

filtrada, que me dura. 